\title{
TEOLOGI, KEKUASAAN, DAN KEADILAN \\ DALAM PERSPEKTIF SEJARAH ISLAM
}

Oleh:

Saefur Rochmat

\begin{abstract}
It is very often for some people to define theology as the core of Islamic teachings in the regard of its content as the science of God. It has Arabic similar terms such as Aqidah and Kalam for explaining the principles of God. It is not surprisingly that Moslem should deal with the issues of theology since the early history of Islam, but why do appear some conflicts in the matters of theology.

Theological controversies are something inherent regarding theology is the result of man's thinking which are bound by the limits of space and of time as the contexts. In other words, theology is the application of the principle of universalism of Islamic teachings in the certain contexts of space and time. Consequently theology is improperly to be claimed as having a universal application. That is why theology is different from iman (belief). It is believed by the Sufis who evaluate correctly that theology does not have an in-depth feeling of spirituality due to its main focus on the use of ratio for the elaboration. Meanwhile iman exists in all religions theology exists in the religions which deal with the matters of worldly affairs, especially in monotheist religions such as Yew, Christian, and Islam.

Theology is in great need at the time of crisis such as at the time of the death of Muhammad PBUH the prophet. Indeed at that time theology has not developed well and be arranged systematically as today. We have some theological groups such as Shiite, Sunni, Khawarij. And in Indonesia we have Muhammadiyah, Nahdlatul Ulama, and PKS which all of them come from the Sunni sect. It is possible to notice them from their different socio-cultural background. In other words, socio-cultural background influence the form of theology.
\end{abstract}

Keywords: theology, belief, Sunni, Shiite, Muhammadiyah, NU, and PKS.

\section{A. PENDAHULUAN}

Sebelum bicara panjang lebar tentang permasalahan teologi, kekuasaan, dan keadilan dalam Islam saya ingin mendudukkan permasalahan dalam suatu kerangka yang memungkinkan adanya interplay teologi, kekuasaan, dan keadilan. Secara harfiah teologi berarti ilmu mengenai Tuhan, dan implikasinya agama seolah-olah identik dengan teologi. Walaupun Islam menganggap penting persoalan teologi, tetapi Islam tidak dapat disamakan dengan teologi Islam. Satu-satunya hal yang bisa dikatakan milik semua umat Islam dan 
menjadi tempat rujukan bagi semua Muslim adalah Al Kur'an. Memang dari satu sumber ini memancarkan berbagai wajah Islam seperti terlihat dalam berbagai macam aliran teologi dalam Islam.

Dalam Islam, teologi seringkali disebut dengan ilmu aqidah atau ilmu kalam, karena teologi mengajarkan pokok-pokok keyakinan pada Tuhan. Memang teologi dibangun diatas unsur-unsur keyakinan, namun teologi tidak dapat disamakan dengan iman/keyakinan (belief) karena makna dari iman (belief) lebih luas dari aqidah. Iman memiliki karakteristik dan ciri-ciri tertentu, tetapi pada dasarnya iman tidak memiliki "bentuk" karena bersifat konseptual dan teoritikal sebagaimana dijelaskan dalam Al-Kur'an Ali Imran 193. Oleh karena itu gerakan purifikasi seringkali mengalami kesulitan karena bid'ah dalam urusan agama seringkali bercampur dengan bid'ah dalam budaya karena ke dalam budaya telah disuntikkan dengan nilai-nilai agama. ${ }^{1}$

Adalah kurang tepat menyamakan teologi dengan iman karena teologi lebih merupakan hasil usaha pemikiran manusia, ${ }^{2}$ sedangkan iman lebih mementingkan hasil olah perasaan manusia dalam rangka memahami realitas eksistensi Tuhan (Absolute Truth, Ultimate Truth). Oleh karena itu munculnya aliran-aliran teologi (kalam) dalam Islam mendapatkan tantangan yang hebat dari kaum Sufi. Kaum Sufi mengkritik secara meyakinkan bahwa teologi bersifat elitis karena hanya mereka yang memiliki kemampuan intelektual yang tinggi yang dapat mengembangkan teologi. Kaum Sufi juga menilai kalau pemikiran intelektual tidak dapat menjelaskan semua permasalahan agama yang seringkali bersifat misteri. Bahkan kaum Sufi menilai pemikiran teologis bersifat kering, karena tidak melibatkan aspek perasaan, sesuatu yang sangat fundamental dalam agama sebagai keterkaitan hati berserta dengan makna mendalam yang menyertainya.

Sebaliknya, kaum Sufi menempuh aspek perasaan dalam rangka mengenal realitas mutlak. Aspek perasaan memang memiliki daya jangkau yang lebih luas dari teologi karena aspek perasaan dimiliki oleh siapa saja baik mereka yang pandai maupun mereka yang bodoh. Mereka sama-sama bisa merasakan susah dan bahagia. Kaum Sufi juga lebih mengena dalam mengembangkan sensivitas kesadaran spiritual karena melalui komunikasi

1 Abdullah, M. Amin, 1995, "Pendekatan "Teologis" dalam Memahami Muhammadiyah", Dalam Kelompok Studi Lingkaran (ed.). Intelektualisme Muhammadiyah: Menyongsong Era Baru. Bandung: Mizan \& KSL, hal. 11.

2 Murata, Sachiko, 1996, The Tao of Islam, terj. Rahmani Astuti and M.S. Nasrullah, Bandung: Mizan, hal. 41. 
individual dengan Tuhan melalui berbagai doa-doa (puji-pujian). Aspek "hubungan manusia dengan Tuhan" memang merupakan aspek yang paling asasi dalam agama, sedangkan aspek "hubungan manusia dengan sesama" tidak selalu menjadi sorotan agama. Adanya aspek "huhungan manusia dengan Tuhan" yang menonjol dalam agama-agama Semitis (Yahudi, Kristen, dan Islam) menjadikan mereka digolongkan ke dalam "World Religions", sedangkan agama-agama tradisi cenderung hanya memperhatikan aspek "hubungan manusia dengan Tuhan" baik melalui tindakan memuja kepada yang dianggap "Absolute Truth" maupun dengan menyatukan diri dengan alam. Tidak heran bila praktek sufi atau mistis seringkali dijumpai pada agama-agama tradisi ini.

Dari perbincangan di atas kita tahu bahwa World Religions telah mengembangkan konsep hubungan manusia dengan makhluk lainnya (sesama dan alam). Walaupun demikian, apa yang tertulis dalam kitab-kitab sucinya tidak dapat menjelaskan semua persoalan duniawi karena persoalan duniawi terus bermunculan, sedangkan proses pewahyuannya sudah berhenti. Oleh karena itu, umat beragama merasa perlu melakukan reintrepretasi terhadap kitab suci, sebagai rujukan utamanya, lalu melakukan rekonstruksi terhadap ajaran-ajaran agama itu. Dalam Islam dikenal dengan istilah ijtihad (pembaharuan pemikiran agama) dan lagi-lagi ijtihad tidak bisa disamakan begitu saja dengan ber-teologi karena ijtihad bisa dilakukan di luar konteks berteologi.

Memang tidak salah menghubungkan persoalan teologi dengan masalah kekuasaan dan keadilan karena kedua hal terakhir berkaitan dengan problem keduniawian atau kemanusiaan. Memang agama-agama yang masuk kategori World Religions memiliki ciri-ciri teologis karena berpretensi juga mengatur "hubungan manusia dengan makhluk lainnya". Aspek inilah yang terasa kurang dalam "agama-agama tradisi" sehingga tidak jarang para penganutnya pindah agama ke dalam agama-agama World Religions. Perpindahan agama terjadi karena mereka tidak dapat mencari jawaban persoalan kemanusiaan dalam agama tradisinya. Akan tetapi mereka tidak hanya bersifat pasif, sehingga mereka tetap memelihara" aspek hubungan manusia dengan Tuhan" yang ada dalam tradisinya.

\section{B. PENTINGNYA TEOLOGI DALAM ISLAM}

Sudah dijelaskan di atas bahwa teologi memiliki tempat tersendiri dalam "agama-agama dunia" seperti halnya dalam Islam. Munculnya aliran teologi 
dalam Islam dapat dilacak pada sejarah awal Islam, khususnya sejak komunitas Islam periode Medinah. Sebelum bicara panjang lebar masalah teologi dalam seluruh gerak sejarah Islam maka saya ingin menjelaskan satu hal yang sering dilupakan orang yaitu komunitas Islam pada periode Mekkah. Pada periode Mekah, ajaran agama lebih menekankan "aspek hubungan manusia dengan Tuhan" atau dengan kata lain aspek iman/keyakinan. Memang ayat-ayat yang turun pada periode ini juga mengkritisi keadaan masyarakat pada saat itu, tetapi tidak ada keinginan untuk menggantikan sistem masyarakat pada waktu itu. Nabi Muhammad SAW hanya ingin melakukan "reformasi" dalam sistem masyarakat yang dinilainya telah menyimpang dari semangat awal terbentuknya sistem masyarakat itu. Contohnya, dalam Al-Kur'an Surat AlBaqarah dijelaskan bahwa ibadah haji sebagai salah satu Rukun Islam (kewajiban agama Islam) merupakan warisan sistem Arab. Nabi Muhammad hanya mengkritik ritual ibadah haji yang sudah diselewengkan sebagai arena untuk bermegah-megahan dan membanggakan kebesaran nenek moyangnya.

Dalam periode Mekkah, Islam masih menekankan pada pentingnya iman dalam kehidupan. Iman yang ditekankan oleh Nabi Muhammad adalah "monotheisme" (kepercayaan kepada Tuhan Yang Esa). Walaupun iman seperti ini masih bersifat abstrak, namun para penguasa Quraisy takut terhadap dampak yang disebabkan oleh ajaran Muhammad tersebut, sehingga mereka berusaha menghalang-halangi dakwah yang dilakukan oleh Nabi Muhammad. Sebenarnya mereka sudah mengenal "haji", mereka sudah mengenal akan konsep Tuhan, tetapi lagi-lagi mereka sudah menyelengkan pengertian Tuhan dalam terminologi monotheisme. Perlu diketahui bahwa situasi Arab pada waktu itu berada dalam pengaruh peradaban lain yang lebih dominan seperti Peradaban Persia sehinga mereka memiliki perasaan inferior. Konsekuensinya, mereka mengadopsi tuhan-tuhan dari peradaban lain itu yang disimbolkan dengan berbagai macam patung, karena mereka ragu-ragu dengan keampuhan Tuhan mereka sendiri, yang tidak menjadikan mereka sebagai bangsa yang besar. Hal ini menimbulkan pertanyaan, apakah agama identik dengan kebesaran di dunia ini? Sejarah menunjukkan bahwa antara agama dengan urusan dunia saling berkaitan, sehingga penafsiran agama juga akan sejalan dengan perkembangan sejarah peradaban manusia. 
Dakwah Nabi Muhammad yang ingin menandaskan konsep monotheisme bukanlah sesuatu yang asing dalam tradisi Arab pada waktu itu. ${ }^{3}$ Yang menjadi akar bagi penentangan dakwah Islam adalah implikasi politis dan ekonomis dari ajaran monotheisme itu. Implikasi politisnya, bila mereka mengikuti ajaran Islam maka mereka takut akan kehilangan posisi yang ada, disamping sebagai tanda klannya tunduk kepada klan Nabi Muhammad. Ini adalah suasana psikologis masyarakat kesukuan. Oleh karena itu para pembesar Quraisy sangat gigih menentang Islam. Implikasi ekonomisnya, dengan mengakui Islam maka bisnis patung yang sangat menjanjikan akan lenyap. Tidak heran bila yang gigih menentang Islam adalah para pedagang kaya yang merasa terancam bisnis patungnya. ${ }^{4}$

Saling keterkaitan urusan agama dengan urusan duniawi dapat dilihat dalam gerak sejarah Islam. Tapi disini saya takut kalau sampai ada anggapan bahwa agama yang diridlai Tuhan adalah agama yang mampu mengembangkan kedua unsur (urusan dunia dan sakral) ini secara seimbang. Semua agama adalah valid disisi Allah sejauh pemeluknya berbuat kebajikan di dunia ini demi Allah. Pengidentikan agama yang diridlai Tuhan dengan kesuksesan dalam urusan duniawi akan terbantahkan oleh fakta bahwa Tuhan tidak mengutus para Nabi dalam personifikasi yang selalu sukses secara duniawi. Kita tahu bahwa Nabi Ayub itu sakit-sakitan, Nabi Ibrahim terusir dari tanah kelahirannya, Nabi Musa juga diutus untuk umat Yahudi yang sedang dalam keadaan terhina sebagai budak. Memang penguraian keterkaitan urusan sakral dengan urusan duniawi dimaksudkan untuk mengikuti logika yang runtut sebagai prinsip yang mengatur jalannya alam semesta maupun jalannya sistem kehidupan umat manusia. Akan tetapi kita tidak boleh lupa bahwa Tuhan bisa sewaktu-waktu melakukan intervensi terhadap jalannya sejarah umat manusia karena Dia tidak terikat oleh hukum yang Dia sendiri yang membuatnya.

Keterlibatan Nabi Muhammad dalam sejarah juga harus dipahami dalam keterkaitan antara usaha manusia yang sifatnya mengikuti hukum alam (sunatullah) dengan bimbingan Tuhan dalam perajalan sejarah Nabi Muhammad sebagai orang yang dikasihi-Nya. Ini dapat dilihat dalam Al-Kur'an yang juga memuat "ramalan Nabi Muhammad, yang tentunya atas Petunjuk

${ }^{3}$ Djaka Soetapa, 1980, Konsep Ummah dalam Islam, Yogyakarta: Tiara Wacana, hal. 56-57, 65.

${ }^{4}$ W. Montgomery Watt. 2006. Kejayaan Islam, a.b. Hartono Hadikusuno, Yogyakarta: Tiara Wacana, hal. 3. 
Tuhan" yang ternyata juga terbukti kebenarannya. Ini dapat dilihat dalam AlKur'an Surat Ar-Ruum. ${ }^{5}$ Pada waktu itu umat Islam merasa sedih melihat fakta yang memilukan karena bangsa Romawi yang percaya pada monotheisme dikalahkan oleh bangsa Persia yang memuja dewa Api. Kemudian turun wahyu yang menghibur umat Islam itu: Sepuluh tahun setelah kekalahan dari bangsa Persia, bangsa Romawi akan mengalahkan bangsa Persia. Ramalan dalam bentuk wahyu ini merupakan bentuk intervensi Tuhan, akan tetapi Nabi Muhammad juga memiliki pengetahuan politik global yang dapat dilihat dalam usaha dakwah yang ditujukan kepada pembesar Quraisy, dimana Nabi mengatakan "Saya atau umatku akan dapat mengalahkan bangsa Persia dan bangsa Romawi". Pada waktu itu bangsa Persia dan bangsa Romawi merupakan dua negara superpower pada waktunya. Perkataan itu menjadikan para pembesar Quraisy itu menuduh agama Islam sebagai agama politik.

Kita kembali ke komunitas Islam periode Mekkah dimana Islam tampil dalam wajahnya yang masih abstrak, terutama menjelaskan hubungan vertikal manusia dengan Tuhan dan belum membahas manifestasi iman yang tercermin dalam hubungan horisontal manusia dengan sesama makhluk. Memang iman adalah sesuatu yang abstrak dan tidak ada bentuknya, tetapi iman harus dimanifestasikan dalam kehidupan, karena iman bukan hanya sekedar ucapan (dua kalimat sahadat) tetapi harus dibuktikan dalam bentuk "amal saleh", yang manifestasinya berupa pilihan moral, perbuatan, dan hubungan dengan Tuhan, sesama manusia, dan semua makhluk lainnya. ${ }^{6}$ Islam menuntut iman bukan hanya ucapan saja, dan konsekuensinya "ucapan dua kalimat sahadat" ditempatkan sebagai komponen pertama dalam Rukun Islam (atau, kewajiban agama) dan harus diikuti dengan berbagai kewajiban agama yang lain seperti shalat, zakat, puasa, dan haji.

Sebenarnya sahadat merupakan pernyataan keimanan kepada komunitas, sehingga sudah ada unsur hubungan horisontal. Kalau iman sendiri, seperti yang tercantum dalam 6 "Rukun Iman", sifatnya murni hubungan vertikal. Bila Muslim melakukan ritual-ritual agama yang lebih menekankan pada hubungan vertikal ini maka amal saleh yang muncul akan berbentuk "kesalehan pribadi", sebagaimana ditekankan dalam "agama-agama tradisi". Dalam pandangan "Islam kaffah" (Islam yang sempurna), kesalehan pribadi harus diikuti dengan

5 Syari'ati, Ali, 1992, Membangun Masa Depan Islam, translated by Rahmani Astuti, Bandung: Mizan, hal. 103-105.

6 "Mu'tazilah", in http://en.wikipedia.org/wiki/History of theology, hal.3. 
bentuk-bentuk "kesalehan sosial", sebagaimana dengan "Rukun Islam" yang menghendaki adanya keterlibatan dengan komunitas. Keterlibatan Islam dalam sejarah ini sejalan dengan misi diutusnya umat manusia ke bumi yaitu sebagai "khalifah fil ardhi" (penguasa di bumi), disamping sebagai "'abdullah" (hamba Allah). Seorang dianggap Muslim bila dia menjalankan Kewajiban Islam seperti yang tertera dalam Rukun Islam, sehingga menjadi Muslim tidak harus mendalami masalah teologi.

Kalau kita lihat pelaksanaan Rukun Islam maka haji hanya berlaku bagi mereka yang mampu, sedangkan yang menjadi pusat perhatian adalah shalat karena hal ini merupakan bentuk komunikasi langsung dengan Tuhan dan diharapkan bisa membentuk manusia yang "taqwa", yaitu manusia yang menjalankan segala perintah-Nya dan menjauhi segala larangan-Nya". Orang yang shalat tapi masih melakukan tindakan keji seperti korupsi maka dia termasuk orang yang fasik, seperti tercantum dalam Alquran surat al-Ma'un (45) "Celakalah orang yang shalat tetapi melalaikan shalatnya". ${ }^{7}$ Pelajaran yang dapat dipetik dari pesan taqwa ini adalah kita tidak disuruh mengubah sistem masayarakat yang ada tetapi disuruh berbuat baik dan mencegah dari perbuatan munkar dalam konteks sistem yang ada. Adalah tepat ucapan Joseph Schact bahwa kewajiban Islam dapat dijalankan tanpa adanya regulasi negara karena Islam dapat dipraktekkan dalam suatu komunitas. Kewajiban-kewajiban agama ini diatur bukan dalam masalah teologi tetapi dalam syariah (hukum Islam), atau lebih tepatnya dalam fiqih (hukum legal Islam). Bila prioritas dari Islam adalah menjalankan kewajiban-kewajiban agama seperti tertera dalam Rukun Islam maka tidak perlu "kompetisi" dalam urusan duniawi, bagi mereka yang menganut teologi jabariyah (menyerah pada takdir). ${ }^{8}$ Sebenarnya kewajiban agama seperti zakat dan haji menuntut Muslim untuk berkompetisi dalam urusan duniawi. Memang kompetisi diperbolehkan dengan mengindahkan prinsip-prinsip moralitas. Mengenai gejala fundamentalisme yang merebak akhir-akhir ini dikarenakan mesjid tidak dibangun atas "landasan taqwa" (ussisa 'ala taqwa) tetapi dijadikan ussisa 'ala siyasah (dijadikan basis perpolitikan), padahal orientasi politik tiap kelompok berbeda-beda. ${ }^{9}$ Oleh karena itu, penting

\footnotetext{
7 Yusman Roy, "Akhlak Mulia, Buah Shalat Berkualitas", dalam http://islamlib.com/id/index.php?page=article\&mode=print\&id=1267 hal. 2 .

8 W. Montgomery Watt, Kejayaan Islam, a.b. Hartono Hadikusuno, Yogyakarta: Tiara Wacana, hal. 15.

${ }_{9}$ K.H. Mukhlas Syarkun, "Semangat Siasah Lebih Dominan Daripada Takwa", dalam http://islamlib.com/id/index.php?page=article\&mode=print\&id=1216, hal. 1 .
} 
kiranya mesjid dijadikan sebagai arena publik dimana berbagai macam ide diperbolehkan dan karenanya penguasaan mesjid oleh sekelompok orang perlu dicegah.

\section{KONFLIK TEOLOGIS DALAM ISLAM}

Yang sangat menyedihkan adalah konflik terjadi dengan sesama saudara dan penyebabnya adalah rebutan warisan "klaim kebenaran". Ini bisa dilihat dalam kasus Tradisi Ibrahim dimana rebutan warisan terjadi antara Yahudi, Kristen, dan Islam. Rebutan warisan "klaim kebenaran" apalagi sesama "saudara kandung" adalah tidak etis, karena mereka diharapkan bisa memelihara "warisan monotheisme" dari Tradisi Ibrahim itu. Perbedaan agama merupakan sunnatullah pluralitas kemanusiaan itu sendiri. Masing-masing memiliki keunikan "jalan" sendiri-sendiri, tetapi bukan berarti mereka tidak memiliki "tujuan" yang sama. Sebenarnya kemunculan agama itu dapat dilihat dalam kacamata dialektika. Karena Yahudi sangat menekankan aspek "hukum"10 yang menjadikan non-Yahudi sulit menganut agama Yahudi maka lahirlah Kristen yang lebih menekankan aspek "belief" yang sifatnya cair dan masih abstrak sehingga bisa menjustifikasi berbagai sistem yang sudah ada, sedangkan Islam berusaha menggabungkan aspek "hukum" dan "belief" sekaligus. Hal ini bukan berarti Islam lebih unggul, melainkan untuk memenuhi kebutuhan manusia yang memiliki karakteristik sintesis itu. Aspek "belief" dalam Islam tercermin dalam periode Mekkah, sedangkan aspek "hukum" tercemin dalam periode Medinah dimana Nabi memiliki "kekuasaan duniawi" yang berpretensi mengatur jalannya peradaban di muka bumi. ${ }^{11}$

Konflik teologis Islam dengan Yahudi dan Kristen yang sering menghalangi sikap toleransi pihak Islam adalah persepsi umat Islam bahwa Yahudi dan Kristen tidak pernah mau mengakui esksistensi Islam seperti tercemin dalam sejarah awal Islam. Hal ini terekam dalam Alquran surat alBaqarah 120. Gus Dur menilai surat itu ditujukan kepada Nabi Muhammad, bukan kepada semua Muslim, ketika Nabi menghadapi orang Yahudi dan Kristen yang militan dan mereka tidak mau mengakui eksistensi Islam. Masalah utama yang mendorong mereka mengingkari Piagam Medinah bukanlah motivasi agama, tetapi motivasi politik dan karenanya Nabi memerangi mereka

${ }^{10}$ Djaka Soetapa, op. Cit., hal. 69.

11 Nasr, Seyyed Hossein, 1994, Ideals and Realities of Islam, London: Allen and Unwin, hal 146-147. 
bukan berdasarkan pertimbangan agama tetapi berdasarkan pertimbangan politik. Dengan demikian surat al-Baqarah 120 tidak berlaku unviersal tetapi dalam konteksnya karena ternyata sikap tidak mau menerima eksistensi Islam sudah tidak berlaku lagi dengan adanya "Vatican Conciliation II" pada tahun 1962-1965, disamping minoritas Islam di Eropa memiliki kebebasan juga dalam menjalankan agamanya. Oleh karena itu, surat al-Baqarah 120 merupakan perintah historis dengan konteks politik bukan konteks religious. ${ }^{12}$

Permasalahan "klaim kebenaran" sangat menonjol dalam "World Religions" karena mereka sangat menekankan peranan individu dalam sejarah sehingga dikenal dengan "personal religion". Tidak mengeherankan bila umat Kristen dan Islam dalam berperang membawa-bawa "atas nama agama" dan para teroris mengebom tempat ibadah atas nama Tuhan. Karen Amstrong menilai "agama tradisi" cenderung bersifat toleran karena sifatnya yang "impersonal religions", dimana mereka cenderung bersifat kompromi dalam menghadapi sistem keyakinan yang berbeda. ${ }^{13}$ Saya tidak menyarankan agar kita mengkompromikan keyakinan kita, tetapi yang lebih penting adalah saling menghormati keyakinan masing-masing dan tidak menganggap agama sendiri sebagai yang paling benar karena setiap agama menawarkan suatu jalan tersendiri yang unik bagi para penganutnya.

Masalah teologis dalam Islam muncul ketika Islam bersentuhan dengan masalah "duniawi", terutama urusan politik. Masalah teologi muncul ketika Nabi Muhammad wafat, sementara Nabi tidak menunjuk penggantinya ataupun mempersiapkan prosedur suksesi kepemimpinan. Alquran juga tidak mengatur masalah suksesi ini karena Alquran memang bukan kita politik. Memang Alquran merasa berkepentingan dengan urusan duniawi, tetapi tidak masuk akal bila Alquran memuat secara detail urusan duniawi mengingat urusan duniawi senantiasa mengalami perubahan. Alquran hanya memberikan "petunjuk etik" dalam mengatur urusan duniawi, termasuk dalam urusan politik.

Memang politik sangat krusial dalam agama, tidak terkecuali dalam Islam. Tidak mengherankan bila sejarah "World Relgions" penuh dengan gerakan politik untuk mewujudkan keselamatan di dunia ini dalam bentuk

${ }_{12}$ Abdurrahman Wahid, 2000, "Islam: Punyakah Konsep Kenegaraan?", dalam Shaleh Isre ed., Tuhan Tidak Perlu Dibela, Yogyakarta: LkiS, hal. 108-109.

${ }^{13}$ Amstrong, Karen, (2002), Sejarah Tuhan, translated by Mizan team, Bandung: Mizan, p. 164. 
keadilan, kesejahteraan, keamanan dan kebebasan sebagai karakteristik Tuhan di dunia ini. Karen Amstrong benar bahwa nilai-nilai eksternal sejarah (politik) bagi Muslim bukanlah perhatian kedua karena salah satu karakteristik dari Islam adalah pensakralan sejarah. ${ }^{14} \mathrm{Hal}$ ini berkaitan dengan status manusia sebagai khalifah fil ardhi (penguasa di dunia) yang mengindikasikan perlunya "kekuasaan" untuk memenuhi keselamatan manusia di dunia ini. Misi keselamatan ini merupakan komitmen manusia dalam statusnya sebagai khalifah fil ardhi dalam rangka memenuhi peran lainnya sebagai 'abdullah (hamba Allah). ${ }^{15}$ Oleh karena itu kita tidak dibenarkan mengeksploitasi alam maupun manusia; dengan kata lain manusia diperkenankan memanfaatkannya sesuai dengan proporsinya. Memang banyak yang mengklaim memiliki hak untuk menggunakan kekuasaan untuk mewujudkan Kerajaan Allah di dunia ini. Walaupun saya melihat peranan politik bagi eksistensi agama, namun hal ini tidak berarti bahwa politik harus dimaknai sebagai suatu cara untuk mendapatkan dan mempertahankan kekuasaan negara. Saya lebih cenderung memaknai politik sebagai suatu cara mempertahankan eksistensi agama dengan berbagai cara dalam berbagai aspek kehidupan baik politik, ekonomi, budaya, sosial, dan pertahanan. Mengenai pentingnya politik ini Injil menyebut dengan istilah "Principalities and Powers", yang didefinisikan oleh Wink "powers are the simultanity of an outer, visible structure and an inner, spiritual reality." ${ }^{16}$ Untuk itu kita harus memilih alat-alat politik yang sesuai dengan situasi dan kondisi serta sejarah suatu daerah agar kita dapat memaksimalkan tujuan penggunaan alatalat politik tersebut, disamping jangan sampai menodai misi agama untuk melindungi kemanusiaan atau dengan kata lain melindungi hak hidup orang lain.

Sangat sering dipahami kalau politik selalu memiliki implikasi kekerasan, seperti halnya konsep jihad dalam Islam. Jihad merupakan salah satu konsep utama dalam Islam dan dimaknai "usaha dengan sekuat tenaga" dalam semua hal, sehingga salah kalau dipahami sebagai "berperang di jalan Allah". Islam memiliki berbagai macam terminologi jihad seperti jihad paling ringan, jihad kecil, jihad besar, dan jihad akbar. Justru Islam memandang perang merupakan

${ }_{14}$ Armstrong, Karen, 2000, Sepintas Sejarah Islam, A.b. Ira Puspito Rini, Yogyakarta: Ikon Teralitera, hal. ix.

${ }_{15}$ Murata, Sachiko, 1996, The Tao of Islam, terj. Rahmani Astuti and M.S. Nasrullah, Bandung: Mizan, hal. 38.

16 Wink, Walter, 1992, Engaging the Powers: Discernment and Resistence in a World of Domination, Minneapolis: Fortress Press, hal. 13-14. 
jenis jihad kecil. Hal ini dikatakan Nabi ketika baru pulang dari perang Uhud yang menelan korban paling banyak di pihak Islam. Lalu para pengikutnya menanyakan hal itu dan Nabi menjawab jihad akbar adalah jihad melawan hawa nafsu. Hal berikut lebih mencengangkan lagi bagi mereka yang suka menggunakan kekerasan dalam mempertahankan Islam karena Alquran tidak pernah menggunakan kata jihad untuk menyebutkan perang-perang yang dialami oleh Nabi, melainkan dengan kata kootilu dan kata-kata turunannya seperti yang tercantum dalam Alquran surat al-Baqarah 190-193 dan 216. ${ }^{17}$

Memang kekerasan dalam Islam seringkali didorong oleh pemahaman tekstual terhadap Alquran baik dengan adanya ayat-ayat yang menegasikan penganut agama lain seperti tersebut di atas atau menginginkan "sistem" yang dimaksud di dalam Alquran. Bila "sistem" yang dijadikan alasan maka sikap Muslim menjadi anti-modern dan menginginkan Islam pada zaman kejayaannya. Ini merupakan pemahaman Islam yang apologis. Sebenarnya Alquran bukan merupakan suatu "sistem", seperti dikatakan memiliki sistem politik. Istilah kekhalifahan dan Dar al-Islam (negara Islam) tidak terdapat dalam Alquran dan itu hanya terdapat dalam figh (hukum legal Islam) produk pemikir Islam masa klasik. Tentunya figh klasik itu berlaku untuk waktu dan daerah yang sudah ditentukan, sedangkan masa sekarang ini hendaknya perlu dirumuskan figh baru sebagai suatu bentuk dari syariah (hukum Islam). Memang Alquran menyebut "sistem" seperti "sistem masyarakat Arab" tetapi itu hanya untuk menunjukkan bagaimana implementasi prinsip-prinsip moral dan nilainilai univesal.

Persoalan teologi juga menjadi pemicu kekerasan dalam Islam sendiri, namun kita harus melihat bahwa teologi merupakan suatu usaha justifikasi terhadap krisis yang sedang melanda umat Islam. Teologi bukan merupakan penyebab dan yang menjadi penyebab adalah krisis yang melanda umat baik itu krisis psikologis maupun krisis sosial. Akar persoalan teologi mengemukan ketika Nabi Muhammad wafat tanpa meninggalkan pengganti maupun sistem suksesi. Beberapa kelompok ingin menjadi pemimpin baik dari suku-suku di Medinah maupun dari suku-suku dari Mekkah. Suku-suku dari Medinah menarik keinginannya setelah mempertimbangkan maksud awal mengundang Nabi Muhammad adalah untuk menghindari konflik sesama suku. Suku-suku dari Mekkah menandaskan adanya hadits Nabi bahwa yang berhak menjadi

17 Al-Hilalli, Muhammad Taqi-ud-Din dan Muhammad Muhsin Khan, 1996, Interpretation of the Meaning of the Noble Qur'an, Riyadh: Darussalam. 
pemimpin adalah suku Quraisy. Kelompok Quraisy sendiri pecah karena Tradisi Arab Selatan, yang terbiasa dengan sistem keturunan dalam kepemimpinan, menginginkan Ali sebagai khalifah karena dianggapnya mewarisi sifat kepemmpinan Nabi Muhammad. Sedangkan Tradisi Arab Utara, yang terbiasa dengan sistem pemilihan, menginginkan Abu Bakar sebagai khalifah. ${ }^{18}$ Krisis ini bisa diselesaikan dengan bijaksana oleh para sahabat Nabi pada waktu itu, karena Ali berhasil menjelaskan kepada pendukungnya bahwa ia akan bertindak sebagai penasehat para khalifah. ${ }^{19}$

Kita perlu kritis apakah hadits yang menegaskan hak kepemimpinan dalam Islam berada di tangan suku Quraisy itu shahih dan kalau shahih apakah konteks penerapannya tepat. Karena kemudian muncul aliran Mu'tazilah yang bersemboyan la hukma illa lillah (tidak ada hukum kecuali dari Allah) dan jargon inipun muncul sebagai respon terhadap situasi krisis (psikologis) karena kecewa terhadap kesediaan Ali melakukan perundingan dengan Muawiyah. Kita juga bertanya apakah ayat yang dipakai sebagai jargon itu tepat konteksnya? Janganjangan mereka tidak memahami semangat Alquran secara umum dan hanya mengamalkan ayat-ayat secara terpisah-pisah tanpa tahu konteksnya. Persoalan teologis telah menyebabkan konflik yang tidak perlu dalam Islam dan hal ini masih saja berlangsung sampai sekarang ini.

\section{PERSOALAN TEOLOGIS DI INDONESIA}

Mayoritas umat Islam di Indonesia adalah penganut teologi Sunni dan madzah Syafii dalam bidang fiqih. Memang Islam menekankan pada aspek teologi dan hukum sekaligus karena keyakinan teologis harus diterapkan dalam bentuk amal sebagaimana diatur oleh kitab fiqih. Sudah kita ketahui bersama bahwa umat Islam di Indonesia terbelah dalam dua kubu yang berbeda, walaupun perbedaan itu sudah mulai mencair dengan adanya saling komunikasi dan pemahaman di antara mereka walaupun belum seperti yang diharapkan. Walaupun semboyan "purifikasi" Muhammadiyah banyak mendapat pengaruh dari Gerakan Wahabi yang menganut Madzah Hambali tetapi Muhammadiyah tidak mau digolongkan ke dalam pengikut Madzab Hambali.

${ }^{18}$ W. Montgomery Watt, Kejayaan Islam, a.b. Hartono Hadikusuno, Yogyakarta: Tiara Wacana, hal. 16.

19 Abdurrahman Wahid, 2000, "Islam: Punyakah Konsep Kenegaraan?", dalam Shaleh Isre ed., Tuhan Tidak Perlu Dibela, Yogyakarta: LkiS, hal. 1. 
Ternyata teologi Sunni juga mengalami perkembangan yang tidak mudah dicari titik temunya. Persoalan teologi akan terus mengalami perkembangan dalam Islam karena Islam berpretensi ikut mengatur gerak sejarah peradaban umat manusia. Ada dua kecenderungan yang mendorong munculnya aliranaliran teologi, yaitu "ideologi-ideologi dunia" dan keadaan "sosio kultural" masyarakat. Kedua hal inilah yang menggerakan teologi dalam Islam dan hal ini mengarahkan NU mengadopsi jargon "Pribumisasi dan Modernisasi", sedangkan jargon Muhammadiyah adalah "Purifikasi dan Dinamisasi (Modernisasi).

Sekarang NU dan Muhammadiyah sebagai mainstream Islam di Indonesia mengakui Pancasila sebagai landasan bagi kehidupan berbangsa dan bernegara, walaupun hal itu baru secara formal dirumuskan pada tahun 1983 dan 1985 sebagai jawaban terhadap kebijakan asas tunggal Pancasila. Adopsi konsep nation state merupakan keharusan sejarah di era modern ini. Bila umat Islam tidak mau mengadopsi ini maka mereka akan mengalami alienasi dalam kehidupan berbangsa dan bernegara walaupun mereka merupakan mayoritas penduduk Indonesia. Hal ini tentu tidak diharapkan oleh para pemimpin Muslim karena dapat mengarah kepada konflik yang tidak terkendali. Adalah salah bila pemerintah tidak melibatkan partisipasi umat Islam.

Indonesia sudah memiliki dua presiden yang lahir dari tradisi Islam yaitu B.J. Habibie dan Gus Dur, namun mereka berasal dari latar belakang yang berbeda. Meskipun mereka berasal dari tradisi Islam mereka tidak dapat memegang tampuk kepresidenan untuk waktu yang wajar. Hal ini menunjukkan bahwa mereka tidak memiliki legitimasi dari seluruh kalangan umat Islam dan ini menunjukkan Muslim Indonesia belum berhasil mengembangkan dialog yang konstruktif. Krisis kepemimpinan semakin nyata ketika Gus Dur diturunkan sebelum waktunya habis. Kalau saya amati antara Gus Dur dan Amien Rais sudah mengadopsi konsep nation state tetapi mereka gagal menjalin kerjasama karena masalah saling kecurigaan antara "komunitas sosial yang berbeda". Jadi masalah "sosio kultural" telah diangkat menjadi permasalahan "teologis". Ini dapat dilihat dari sikap kalangan Muhammadiyah yang menuduh PKS sebagai alat dari Gus Dur karena PKS mengikuti metode ru'yat (melihat bulan dengan mata) yang digunakan NU dalam menentukan awal dan akhir bulan puasa dan tidak mengikuti metode hisab (berdasarkan perhitungan) yang digunakan oleh Muhammadiyah. Padahal kalau kita percaya pada survey yang dilakukan oleh AMM menunjukkan bahwa 67\% anggota PKS 
berasal dari kalangan Muhammadiyah. ${ }^{20}$ Lagi-lagi masalah "sosio-kultural" diangkat ke dalam persoalan "teologis". Bila kita cermati maka konteks sosialkultural dari PKS dan Muhammadiyah berbeda, walaupun mayoritas anggota PKS berasal dari Muhammadiyah.

Gejala sekresi dapat dilihat lebih awal lagi semenjak Islam memasuki kontak dengan peradaban modern Barat. Hal ini terjadi karena Islam harus melakukan respon terhadap ideologi-ideologi dunia yang berkembang pada saatnya dan masing-masing kelompok Islam tidak mengadopsi ideologiideologi dunia dengan jenis dan kadar yang berbeda. Pertamakali lahir gerakan Islam yang bernama Sarekat Dagang Islam (SDI) yang didirikan oleh $\mathrm{H}$. Samanhudi. Organisasi yang bercorak ekonomi itu menjelma menjadi partai Sarekat Islam pada tahun 1912 di bawah pimpinan HOS Cokroaminoto. Walaupun HOS Cokroaminoto dibesarkan dalam sistem pendidikan modern (Barat), namun dia mendapat dukungan baik dari umat Islam yang berlatar belakang perkotaan maupun pedesaan karena umat Islam sedang menantikan munculnya seorang pemimpin, walau-pun mereka membawa persepsi yang bermacam-macam. Hal itu telah dicermati oleh pihak Belanda untuk menjalankan politik devide et impera (memecah-belah) dengan mengakui cabangcabang SI sebagai organisaasi yang otonom dari pusat (Central Sarekat Islam). ${ }^{21}$

Di dalam SI berkembang berbagai macam pema-haman tentang Islam, dan sikap revolusionernya digerakkan oleh konsep Imam Mahdi (milleniarisme atau mesianisme) dan konsep-konsep komunisme yang radikal itu. Ketika SI (dari sayap kanan maupun kiri) tidak dapat mengambil keputusan yang strategis dalam mengakomo-dasikan konsep-konsep Islam dengan konsepkonsep komu-nisme dengan diberlakukannya monoloyalitas maka SI mengalami perpecahan ke dalam SI Putih dan SI Merah. Hal itu menandai kemunduran SI karena banyak rakyat yang sudah terpengaruh konsep radikal komunisme tidak siap untuk dicap sebagai atheis sehingga tidak mau masuk ke dalam SI Merah karena mengandung resiko yang tidak ringan, sedangkan mau masuk ke dalam SI putih tidak at home karena tidak memberikan jaminan ideologis terhadap keinginannya yang radikal, walaupun pemahaman Islam HOS Cokroaminoto sudah menerima sosialisme. Perpecahan dalam tubuh SI sekaligus menghapus kesempatan Islam untuk tampil sebagai meanstream

${ }^{20}$ AMM, “Beberapa Catatan Pasca Pemilu”, hal. 2.

${ }^{21}$ Sartono Kartodirdjo, 1993, Pengantar Sejarah Indonesia Baru: Sejarah Pergerakan Nasional Jilid II, Jakarta, Gramedia, hal. 108. 
ideologi politik di Indonesia karena kepemimpinan politik nasional segera diambil alih oleh ideologi nasionalisme. Hal itu terjadi karena nasionalisme bersifat open minded (terbuka) dan tidak mau menghakimi pemahaman keagamaan seseorang dengan hukum wajib dan dosa.

\section{REFERENSI:}

"Mu'tazilah", in http://en.wikipedia.org/wiki/History of theology.

Abdullah, M. Amin, 1995, “Pendekatan "Teologis" dalam Memahami Muhammadiyah", Dalam Kelompok Studi Lingkaran (ed.). Intelektualisme Muhammadiyah: Menyongsong Era Baru. Bandung: Mizan \& KSL.

Al-Hilalli, Muhammad Taqi-ud-Din dan Muhammad Muhsin Khan, 1996, Interpretation of the Meaning of the Noble Qur'an, Riyadh: Darussalam.

AMM, “Beberapa Catatan Pasca Pemilu”.

Amstrong, Karen, 2002, Sejarah Tuhan, translated by Mizan team, Bandung: Mizan.

Armstrong, Karen, 2000, Sepintas Sejarah Islam, A.b. Ira Puspito Rini, Yogyakarta: Ikon Teralitera.

Kartodirdjo, Sartono, 1993, Pengantar Sejarah Indonesia Baru: Sejarah Pergerakan Nasional Jilid II, Jakarta, Gramedia.

Murata, Sachiko, 1996, The Tao of Islam, translated by Rahmani Astuti and M.S. Nasrullah, bandung: Mizan.

Nasr, Seyyed Hossein, 1994, Ideals and Realities of Islam, London: Allen and Unwin.

Roy, Yusman, "Akhlak Mulia, Buah Shalat Berkualitas", dalam http://islamlib.com/id/index.php?page=article\&mode=print\&id=1267.

Soetapa, Djaka, 1980, Konsep Ummah dalam Islam, Yogyakarta: Tiara Wacana. 
Syarkun, Mukhlas, "Semangat Siasah Lebih Dominan Daripada Takwa”, dalam http://islamlib.com/id/index.php?page=article\&mode=print\&id=1216.

Syari'ati, Ali, 1992, Membangun Masa Depan Islam, translated by Rahmani Astuti, Bandung: Mizan.

Wahid, Abdurrahman, 2000, “Islam: Punyakah Konsep Kenegaraan?”, dalam Shaleh Isre ed., Tuhan Tidak Perlu Dibela, Yogyakarta: LkiS.

Watt, W. Montgomery,1990, Kejayaan Islam, a.b. Hartono Hadikusuno, Yogyakarta: Tiara Wacana.

Wink, Walter, 1992, Engaging the Powers: Discernment and Resistence in a World of Domination, Minneapolis: Fortress Press.

\section{Tentang Penulis}

Saefur Rochmat lahir di Kebumen 22 Nopember 1968, menyelesaikan pendidikan dasar dan menengah di Kebumen. Dia lulus dari IKIP Yogyakarta tahun 1993 dan langsung menjadi dosen di almamaternya Jurusan Pendidikan Sejarah FISE UNY. Dia melanjutkan studi ke Jurusan Sejarah di UI dan La Trobe University dan memperoleh Master of International Relations dari Ritsumeikan University, Japan. Tulisannya telah diterbitkan baik di jurnal internasional maupun nasional terakreditasi seperti Ritsumeikan International Affairs, International Journal of Social Studies, MILLAH, Hermeneutik, Cakrawala, dan Jurnal Pendidikan dan Kebudayaan. Sekarang dia menduduki jabatan Lektor Kepala dalam bidang Sejarah Indonesia. 